\title{
Multi-Scale Atmospheric Emissions, Circulation and Meteorological Drivers of Ozone Episodes in El Paso-Juárez Airshed
}

\author{
Nakul N. Karle ${ }^{1}$ D, Rosa M. Fitzgerald ${ }^{1, *}$, Ricardo K. Sakai ${ }^{2}$, David W. Sullivan ${ }^{3}$ and William R. Stockwell $^{1}$ \\ 1 Physics Department, The University of Texas at El Paso, El Paso, TX 79902, USA; nnkarle@utep.edu (N.N.K.); \\ William.R.Stockwell@gmail.com (W.R.S.) \\ 2 Atmospheric Science Department, Howard University, Washington, DC 20705, USA; \\ ricardo.k.sakai@howard.edu \\ 3 Center for Energy and Environmental Services, University of Texas at Austin, Austin, TX 78758, USA; \\ sullivan231@mail.utexas.edu \\ * Correspondence: rfitzgerald@utep.edu
}

Citation: Karle, N.N.; Fitzgerald, R.M.; Sakai, R.K.; Sullivan, D.W.; Stockwell, W.R. Multi-Scale Atmospheric Emissions, Circulation and Meteorological Drivers of Ozone Episodes in El Paso-Juárez Airshed. Atmosphere 2021, 12, 1575. https:// doi.org/10.3390/atmos12121575

Academic Editor: Eugene Rozanov

Received: 30 October 2021

Accepted: 24 November 2021

Published: 27 November 2021

Publisher's Note: MDPI stays neutral with regard to jurisdictional claims in published maps and institutional affiliations.

Copyright: (C) 2021 by the authors. Licensee MDPI, Basel, Switzerland. This article is an open access article distributed under the terms and conditions of the Creative Commons Attribution (CC BY) license (https:// creativecommons.org/licenses/by/ $4.0 /)$.

\begin{abstract}
Ozone pollution has been prevalent in the El Paso-Juárez Airshed (EPJA), especially in the past few decades, and it has been on the rise recently. The spatial and temporal distribution of the tropospheric ozone and several key meteorological factors that influence its concentration has not been adequately understood. Therefore, this investigation comprehensively examined 57 high and 48 low ozone episodes occurring in this region during 2013-2019. We found that the interannual ozone concentration in EPJA was strongly affected by anthropogenic emissions. On the other hand, seasonal ozone variations are due to meteorological variables (among them, solar radiation, planetary boundary layer, and winds) in addition to biogenic emission factors. High ozone events are characterized by calm winds, shallow planetary boundary layer (PBL), whereas low ozone events were marked with strong winds, precipitation, and deep PBL. Synoptic and mesoscale wind patterns for these ozone episodes were identified and characterized. Most of the high ozone episodes occurred when an anticyclonic circulation aloft was associated with a 500-mile middle and upper tropospheric high-pressure region over the EPJA. During these events, stable air masses with convective available potential energies (CAPE) values of less than $450 \mathrm{~J} / \mathrm{kg}$ were found. The importance of surface topography is illustrated by the fact that stations close to the Rio Grande River show a bimodal distribution of wind direction according to the valley axis. High ozone episodes occur with a surface easterly wind that is decoupled from winds above the Franklin mountains.
\end{abstract}

Keywords: ozone episodes; synoptic and mesoscale meteorology; planetary boundary layer; transport; atmospheric chemistry; complex terrain; surface winds

\section{Introduction}

Tropospheric ozone $\left(\mathrm{O}_{3}\right)$ is one of the most significant photooxidants formed by sunlight-driven photochemical reactions of nitrogen oxides $\left(\mathrm{NO}_{\mathrm{x}}\right)$ and volatile organic compounds (VOCs) [1,2]. Ozone plays a central role in atmospheric chemistry, and more generally, the $\mathrm{O}_{3}$ distribution and concentration strongly impact atmospheric temperature. The impacts of $\mathrm{O}_{3}$ on human health and plant growth due to chronic and acute exposure are well documented [3-5]. Other studies have shown the adverse health effects of traffic-related air pollutants, including increases in emergency room visits and hospital admissions [6,7].

The neighboring cities, El Paso, Texas, United States and Juárez, Chihuahua, Mexico, share a common airshed, the El Paso-Juárez airshed (EPJA), that frequently has high $\mathrm{O}_{3}$ concentration levels like many major global cities. Every year from May to September $\left(\mathrm{O}_{3}\right.$ season), the EPJA experiences high $\mathrm{O}_{3}$ events. The Texas Commission on Environmental 
Quality (TCEQ), a state agency, monitors the ambient air quality in this region through its monitoring stations, and it reports the exceedance days to the US Environmental Protection Agency (EPA). Apart from being a border region, the EPJA also has numerous distinct geographic and demographic characteristics that make it an interesting site for research into pollution from traffic and resulting asthma cases among young and adults [6].

With a geographical area of over $648 \mathrm{~km}^{2}$ and a combined population estimate of around 2.8 million people, the EPJA is one of the world's largest international airsheds. It has seen substantial urbanization and industrial expansion in recent decades, accompanied by substandard air quality. The deterioration of regional air quality, particularly an increase in high $\mathrm{O}_{3}$ episodes in the last few years, created significant challenges for local and state policymakers [8,9]. The American Lung Association also ranked El Paso as the 13th worst metropolitan area in the country for ozone pollution in its 2021 air pollution report. It assigned the region an " $\mathrm{F}$ " grade due to the frequency of high ozone days (lung.org/research/sota/city-rankings/states/Texas/el-paso). Given the EPJA's current deteriorating air quality, the EPA may declare El Paso County in "non-attainment" for ozone, which would have a significant impact on regional economic development, permitting, and infrastructure project planning.

Over the years, several $\mathrm{O}_{3}$ studies, including field campaigns, have taken place in this region [10-17]. Both experimental [10,13,15] and model simulations [11,12,14,16,17] were performed to quantify the ozone concentrations and meteorological variables contributing to regional $\mathrm{O}_{3}$ episodes. The 1996 Paso del Norte Ozone Study was one of the most comprehensive, which involved comprehensive analysis aimed to understand better the chemical and physical mechanisms that caused high $\mathrm{O}_{3}$ concentrations in the EPJA and nearby areas. MacDonald et al. investigated the meteorological and air quality parameters of some selective high-ozone episodes that occurred in the summer of 1996 [10]. The authors found high morning $\mathrm{CO}, \mathrm{NO}$, and $\mathrm{NO}_{\mathrm{x}}$ concentrations near the emission sources in the EPJ region, as well as weak surface level winds. Brown et al. used experimental data from the 1996 study and performed meteorological simulations for the study region using the High Order Turbulence Model for Atmospheric Circulations (HOTMAC) and evaluated the 13 August 1996 high ozone day. It was found that on the morning of the $\mathrm{O}_{3}$ exceedance day, the PBL growth rate was much slower than the usual days [11]. Lue et al. conducted a sensitivity modeling study for an ozone occurrence of 1996 using the field campaign data. Local sources were found to be major contributors to high ozone events, while long-distance transport of ozone and its precursors appeared to contribute insignificantly [12]. In their study of regional pollution events, Einfeld et al. in 1995 emphasized the importance of investigating the influence of local complex topography on regional high pollution events [13]. All these studies made significant investigations into the different factors contributing to the regional $\mathrm{O}_{3}$ episodes. However, these studies and analyses were limited to specific episodic periods. There have been no extensive studies to investigate local circulation patterns and their effect on $\mathrm{O}_{3}$ episodes. In addition, transport of $\mathrm{O}_{3}$ and its accumulation effect induced by complex topographical features, such as the Rio Grande Valley and surrounding mountains was never performed in this region. The long-term spatial and temporal distribution of $\mathrm{O}_{3}$ concentrations in this region has not been adequately examined, along with many key meteorological factors that influence it. Therefore, comprehensive long term research analyzing the historical $\mathrm{O}_{3}$ events is critical for better understanding the meteorological drivers of these pollution events.

In this work, we combined observations and statistical analysis to examine the meteorological variables driving $\mathrm{O}_{3}$ events in EPJA. We present the probable mechanisms of severe pollution events in this region from synoptic conditions, local circulations, emission concentrations, and planetary boundary layer (PBL) structure. This study presents a new understanding of the spatial and temporal distribution of $\mathrm{O}_{3}$ episodes events in EPJA. Our study is especially important due to the complex terrain of the region. This research examines the important roles of multiscale circulation patterns and meteorology in regional $\mathrm{O}_{3}$ episodes. The relationships between synoptic patterns, PBL structure, and 
$\mathrm{O}_{3}$ concentrations in EPJA have not been widely examined in the past due to a scarcity of PBL observations. Furthermore, during $\mathrm{O}_{3}$ events (both high and low), surface and aloft circulations can influence surface meteorological factors impacting the PBL-Height (PBLH). As a result, we present the effects of large-scale circulations and the PBL structure on regional $\mathrm{O}_{3}$ occurrences using a CL31 ceilometer.

In Section 2, we describe the methodology, using both observational and modeled data. In Section 3, we present our results. Section 4 provides an elaborate discussion.

\section{Methodology}

\subsection{Site Description and Terrain}

The city of El Paso (ELP), Texas (latitude: $31^{\circ} 47^{\prime} 20^{\prime \prime} \mathrm{N}$; longitude: $106^{\circ} 25^{\prime} 20^{\prime \prime} \mathrm{W}$; elevation: $1145 \mathrm{~m}$ asl), and the city of Ciudad Juárez (CDJ), Chihuahua, Mexico, constitute the 2nd largest conurbation on the USA-Mexico border and this region has the Western Hemisphere's largest bilingual and binational workforce. The two cities are separated by the Rio Grande River and connected by three international bridges. According to the US Census Bureau's 2015 estimate, ELP has a population of approximately 835,593 people. CDJ has over 2 million people, and it is the most populous city in the Mexican state of Chihuahua. CDJ is also one of North America's leading industrial hubs. On the other hand, El Paso is the fifth-largest city in Texas and the 23rd largest in the United States, with approximately $648 \mathrm{~km}^{2}$. The EPJA is in the Chihuahua desert and has 300 sunny days per year on average. This region experiences a dominant northerly wind flow in the cooler months of October through February, followed by a west-southwest flow in the spring from March into early June and then a distinct shift to prevailing southeast winds marking the arrival of the American monsoon season of July through mid-September. This region's climate is hot and dry in the summer and mild and dry in the winter. A combination of local dry environment, high temperatures, availability of $\mathrm{NO}_{x}$, and $\mathrm{VOC}$ leads to high $\mathrm{O}_{3}$ episodes in EPJA, which peak during June and July [8].

EPJ has a complex terrain, with both downtown and surrounding areas in a valley, as seen in (Figure 1). Because of erosion, the Franklin Mountains are separated into three sections: one in New Mexico, one in Texas, and one in both. Narrow channels can be seen bound tightly together by mountains. This diverse terrain inside a mountain range creates micro-climatic variations over short distances. North Franklin, at $2192 \mathrm{~m}$, is EPJ's highest point and Texas's 27th highest peak. The southeast of the Franklins is called the lower valley, and the west to the northwest area is called the upper valley (Figure 1). The Juarez Mountain, located around $10 \mathrm{~km}$ southwest of Franklin Mountain, has an elevation of $1600 \mathrm{~m}$ and is flat-conical in form, with its tip pointing north-northwest (Figure 1) [18]. 


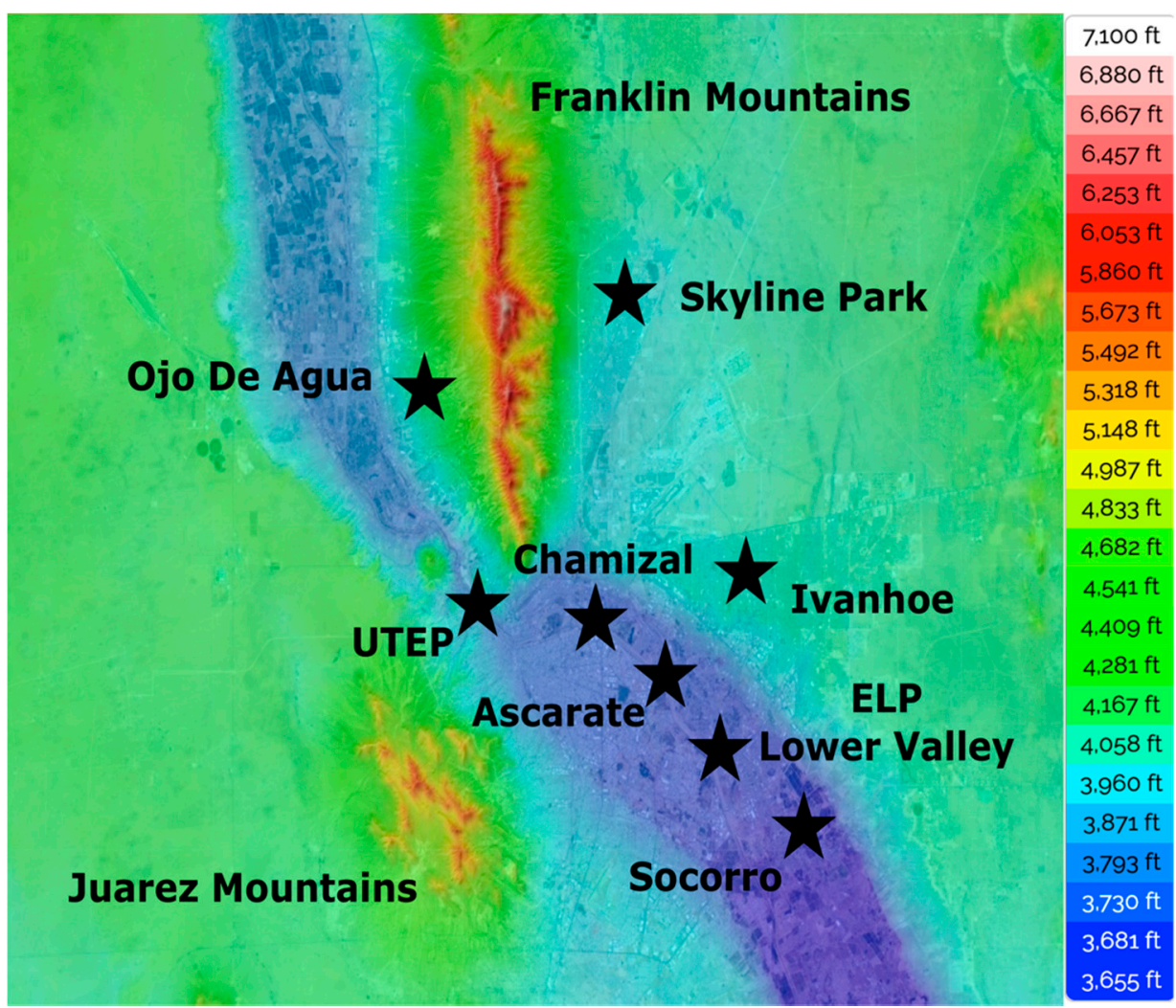

Figure 1. Complex orography of the EPJ region showing apparent elevations in the downtown part and along the banks of the Rio Grande River and the surroundings. Location of Continuous Ambient Air Monitoring Stations (CAMS) operated by the Texas Commission on Environmental Quality (TCEQ): CAMS 12 (UTEP), 41 (Chamizal), 37 (Ascarate), 36 (El Paso Lower Valley), 49 (Socorro), 414 (Ivanhoe), 72 (Skyline) and 1021 (Ojo De Agua).

\subsection{Observational Data and Modeling}

\subsubsection{Local Meteorological and Ozone Data}

Surface $\mathrm{O}_{3}$ and meteorological data with a temporal resolution of $1 \mathrm{~h}$ were obtained from the TCEQ Continuous Ambient Air Monitoring Stations (CAMS) located at various locations in ELP. A Teledyne API 400 was used to monitor ozone at the CAMS. ELP has twelve CAMS in total, with seven stations measuring $\mathrm{O}_{3}$ concentrations. CAMS 12 at UTEP (1158 m ASL), CAMS 41 at Chamizal (1122 m ASL), CAMS 37 at Ascarate Park (1122 m ASL), and CAMS 49 at Socorro Hueco (1117 m ASL) are important for this study. Figure 1 depicts the locations of these four major CAMS, as well as CAMS 1021 at Ojo De Agua (1253 m ASL), CAMS 72 at Skyline Park (1201 m ASL), CAMS 414 at Ivanhoe (1212 m ASL), and CAMS 36 at El Paso Lower Valley (1116 m ASL). CAMS 12, 41, 37, 36, and 49 can also be seen along the Rio Grande valley. CAMS 1021 and 72, on the other hand, are located at the foothills of the Southern Franklin Mountains. CAMS 12, located on the campus of the University of Texas at El Paso (UTEP), is the most active station, having been operational since 10 June 1981 and continuously collecting air-quality and meteorological data. Cumulative $\mathrm{O}_{3}$ concentrations from all regional CAMS is also available on the EPA's website (www.epa.gov / outdoor-air-quality-data (accessed on 15 October 2021)). The $\mathrm{O}_{3}$ observations are reported in parts per billion per volume (ppbv). Vertical profiles were obtained from the nearest National Weather Service (NWS) station located at the Santa Teresa, New Mexico, $\sim 20 \mathrm{~km}$ away from UTEP.

\subsubsection{Vaisala Ceilometer Data}

The aerosol backscattering profiles obtained from the Vaisala Ceilometer CL31, located at UTEP, were used to calculate the PBLH during the study period 2013-2019 This 
instrument was installed in 2015 and has been operational and collecting data since then $[8,9,18,19]$. It is an eye-safe single-lens ceilometer operating at a wavelength of $905 \pm 5 \mathrm{~nm}$, a single $1.2 \mu \mathrm{J}$ per pulse with a time span of $110 \mathrm{~ns}$. The laser is an InGaAs MOCVD diode with a pulse frequency of $10 \mathrm{kHz}$, and the measurement range is from 0 to $7.7 \mathrm{~km}$. More detailed descriptions of the instrument and its functionality are available $[20,21]$. The spatial and temporal resolution of the collected data for this project were $10 \mathrm{~m}$ and $15 \mathrm{~s}$, respectively. The measured aerosol backscatter profiles were imported into Vaisala's proprietary boundary layer software BL-view version 2.1, which identified the boundary layer heights using the gradient method. PBLHs were reported every $16 \mathrm{~s}$, averaged over appropriate intervals, and visually inspected to determine the PBLH.

\subsubsection{Radio Wind Profiler (RWP)}

The radar wind profiler (RWP) in the EPJA is a Scintec LAP 3000 radar wind profiler located at the Socorro Hueco CAMS 49. It is a four-panel 915-MHz radar wind profiler to observe vertical profiles of the three-dimensional wind. The LAP 3000 generated continuous and real-time vertical profiles of horizontal wind speed, direction, vertical wind speed, and turbulence in the PBL and beyond, used in models and tools, such as the Hybrid Single-Particle Lagrangian Integrated Trajectory model (HYSPLIT). It measured wind speed and direction using two vertical beams, measuring doppler along each beam between $137 \mathrm{~m}$ (449 feet) and $3601 \mathrm{~m}$ (11,814 feet) above ground level. Ecklund et al. have discussed in detail the profiler's original design in their work [22].

\subsubsection{Hybrid Single Particle Lagrangian Integrated Trajectory Model (HYSPLIT)}

The HYSPLIT model was developed and is maintained by the National Oceanic and Atmospheric Administration's (NOAA) Air Resources Laboratory (ARL) (Stein et al. 2015) [23]. It is a well-known trajectory model for pollutant transport, dispersion, and deposition within a well-mixed PBL. In this work, the HYSPLIT was used to model mesoscale air movement beyond the EPJA. A comparison was performed for $\mathrm{O}_{3}$ exceedance days with other summer days selected at random. HYSPLIT Back-trajectories were run for $48 \mathrm{~h}$ from $50 \mathrm{~m}, 100 \mathrm{~m}$, and $300 \mathrm{~m}$ above the ground level (AGL) at noon MST (19 UTC) from central El Paso. These altitudes were selected to represent the lower levels in the troposphere through which the air mixes vertically midway, although mixing does occur up to higher altitudes.

A comparison of the ensemble of back-trajectories distribution was performed for 57 ozone exceedance days with 57 other summer days selected at random. Each backtrajectory was $24 \mathrm{~h}$ long started at noon MST from the center of the EPJA at $300 \mathrm{~m}$ above the ground level. The hourly points on a trajectory were referred to as endpoints. The random dates were selected to have a similar distribution within the months of the ozone season to the high ozone days. Maps were made of the trajectory hourly endpoints, and the hourly points for high ozone days were summarized in contour plots. The air parcel fetches associated with high ozone days showed a preponderance of upwind trajectories to the southeast into northern Mexico and West Texas, while the random fetches were more broadly distributed to the northwest and southeast.

Using back-trajectories for many days, one can examine whether patterns exist on higher ozone days than on all days in general. The potential source contribution function (PSCF) is a conditional probability function used to estimate possible upwind source areas from back-trajectory calculations. The PSCF is related to a residence time analysis in that it is based on the passage of back trajectories through upwind areas. However, the PSCF is based on the ratio between the number of back trajectory endpoints in a specific upwind area on high ozone days to the number of back trajectory endpoints in the specific upwind area using all days. 


\subsubsection{Synoptic Scale Conditions}

The EPJ sister cities are in the Rio Grande River basin and shared by the US states of Texas and New Mexico and by the Mexican state of Chihuahua. The elevation of the metropolitan area is $~ 1200 \mathrm{~m}$ MSL and of surrounding mountains $2000-4000 \mathrm{~m}$ MSL. Aloft large-scale atmospheric circulation patterns strongly influence regional and local weather conditions. We investigated the relationship between the $\mathrm{O}_{3}$ episodes in the EPJA and the large-scale conditions aloft and identified patterns associated with the high $\mathrm{O}_{3}$ episodes. We classified 57 high $\mathrm{O}_{3}$ days along the synoptic configurations existing over the EPJ region.

During the $\mathrm{O}_{3}$ season, the synoptic types over the EPJA were determined by manually classifying 500 and $750 \mathrm{hPa}$ circulation patterns, [24]. The 500-hPa level was specifically chosen since the large-scale patterns are smoother and thus much easier to place confidently into the appropriate categories using a manual approach. Additionally, $500-\mathrm{hPa}$ patterns are linked to patterns in the lower troposphere and at the surface. The first stage of synoptic-climatological research classifies atmospheric circulation, which relates circulation patterns to regional ozone episodes [25]. This manual approach promoted a deeper understanding of the synoptic subtleties better than an automated procedure. The gridded 500-hPa geopotential height data were extracted from National Centers for Environmental Prediction-National Center for Atmospheric Research (NCEP_NCAR) and Weather Prediction Center (NCEP_WPC).

\section{Results}

\subsection{Analysis of Inter-Annual Variations of Ozone Exceedances in EPJA}

Ozone exceedance events, also known as $\mathrm{O}_{3}$ action days, occur when an 8-h $\mathrm{O}_{3}$ average concentration exceeds $70 \mathrm{ppbv}$. The EPJA region was previously defined as an $\mathrm{O}_{3}$ non-attainment region but achieved attainment in 2008 [26,27]. Both El Paso and Juárez experienced 335 high ozone episodes over the last two decades (2000-2020). In Figure 2, we have the total number of high ozone events that occurred each year from 2000 to 2020 recorded by all the CAMS in the El Paso region. As seen in Figure 2, from 2000-2008 the region consistently recorded a large number of high $\mathrm{O}_{3}$ episodes each year. However, after 2008, the number of high $\mathrm{O}_{3}$ episodes per year dropped significantly. Additionally, after 2016, the number of high ozone events per year has begun to rise again. This precipitous drop in the number of high $\mathrm{O}_{3}$ episodes and the sudden increase in their number after 8 years was examined to evaluate the influences of mobile emissions on high $\mathrm{O}_{3}$ concentration levels.

The VOCs in the atmosphere are emitted by a variety of sources, both anthropogenic and biogenic. According to Solomon et al. [28], the total amount of reactive VOC emissions from biogenic sources in the United States is approximately 1.4 times greater than that from anthropogenic sources. Emissions from mobile sources are the dominant source of $\mathrm{NO}_{\mathrm{x}}$, whereas the dominant source of VOC emissions is local residential and industrial areas, according to historical emissions data for EPJA [29]. Automobiles, trucks, and trains are examples of mobile sources, whereas residential areas, business districts, and minor industrial zones are local sources [30]. A study conducted by Shelton et al. in 2016 emphasized the impact of idle automobiles in heavy or stop-and-go traffic [31]. Pollutants released as a result of idling motor vehicles have a major impact on regional air quality.

Border ports of entry (POEs) in the El Paso region are of special concern due to long lines of commercial and passenger vehicles traveling north and south, as well as long wait periods at inspection stations. Each POE has US Customs and Border Protection stations, allowing for legitimate international travel and trade but traffic tends to backup during the day with cars and heavy-duty vehicles, such as freight trucks, waiting for many hours to cross the international border between the United States and Mexico. These waiting motor vehicles are significant producers of $\mathrm{O}_{3}$ precursors at EPJ, in contrast to non-border cities elsewhere in the United States. 


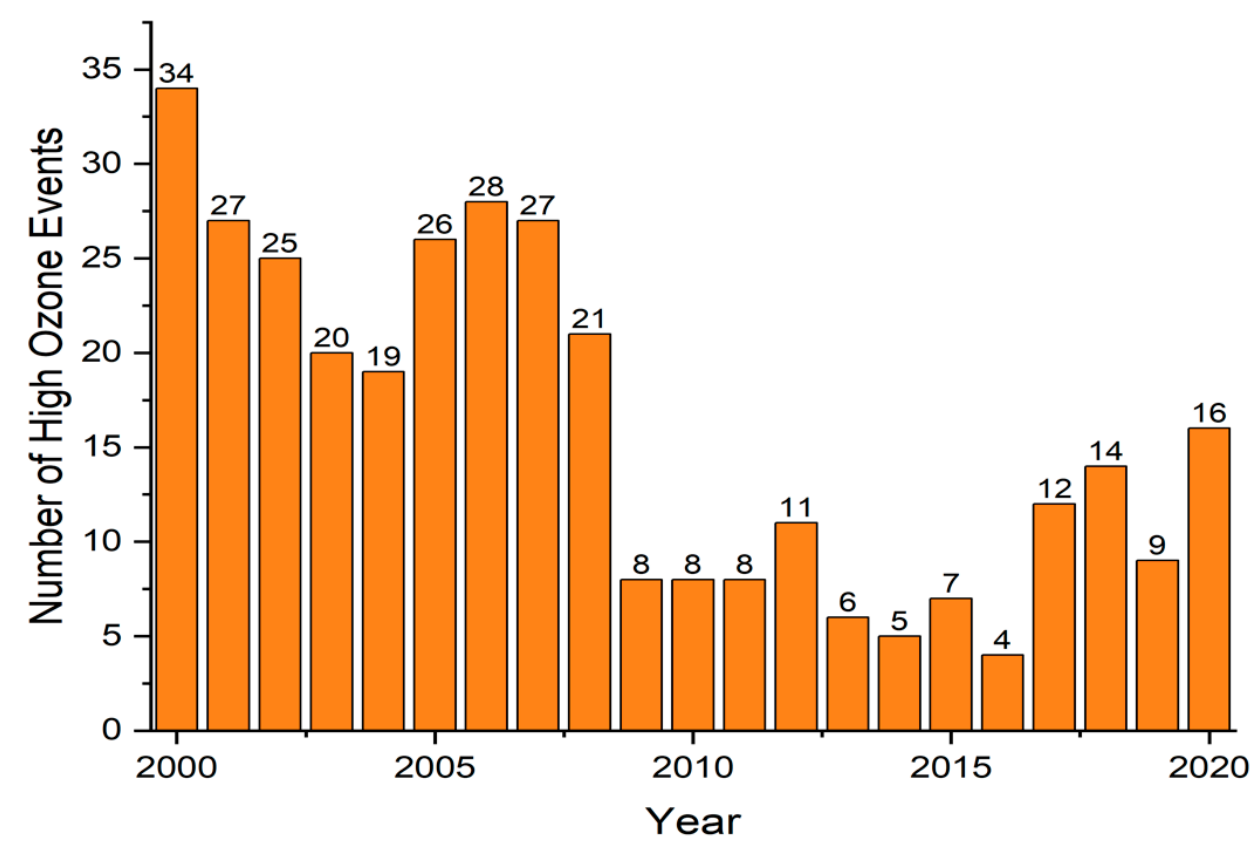

Figure 2. Distribution of the number of high ozone episodes in the last two decades (2000-2020) as recorded by all the CAMS in El Paso. Source: U.S. EPA AirData (https://www.epa.gov/air-data (accessed on 04 June 2021)).

Figure 3 shows that 2008-2009 was a recessionary year in which the US and Mexican economies suffered. The effect of the recession is also reflected in commercial and private vehicle border crossings. This era, denoted by the grey tint, shows a rapid decrease in the number of small and large vehicle crossings. Manufacturing companies in this region were severely impacted by the recession, resulting in a decrease in industrial activity [32]. Violent crime in Mexico from early 2007 to early 2013 was another major factor that contributed to the decrease in border crossings and population in Juarez. Reduced traffic congestion, short wait times along the international border because of fewer crossings, and a reduction in industrial emissions all contributed significantly to the decline in regional $\mathrm{O}_{3}$ exceedance events. The yearly number of high $\mathrm{O}_{3}$ occurrences increased in 2017, after being low for eight years from 2009, with the lowest number of $\mathrm{O}_{3}$ exceedances reported in 2016 (Figure 2). Reports published by Environment Texas (https://environmenttexas.org/) show large amounts of unauthorized emissions, such as $\mathrm{NO}_{x}$ and VOCs $\left(\mathrm{O}_{3}\right.$ precursors $)$ from the local industrial facilities especially in the year 2017 (23,288 pounds) and 2018 $(4,892,945$ pounds). Such a large amount of ozone precursors emitted in the air contributed to air pollution events including the high $\mathrm{O}_{3}$ concentration levels. This helps us explain the sudden rise in the number of high ozone in the respective years. The 2019 published report indicated a reduction in emissions (76,287 pounds), a 98\% reduction compared to 2018. 


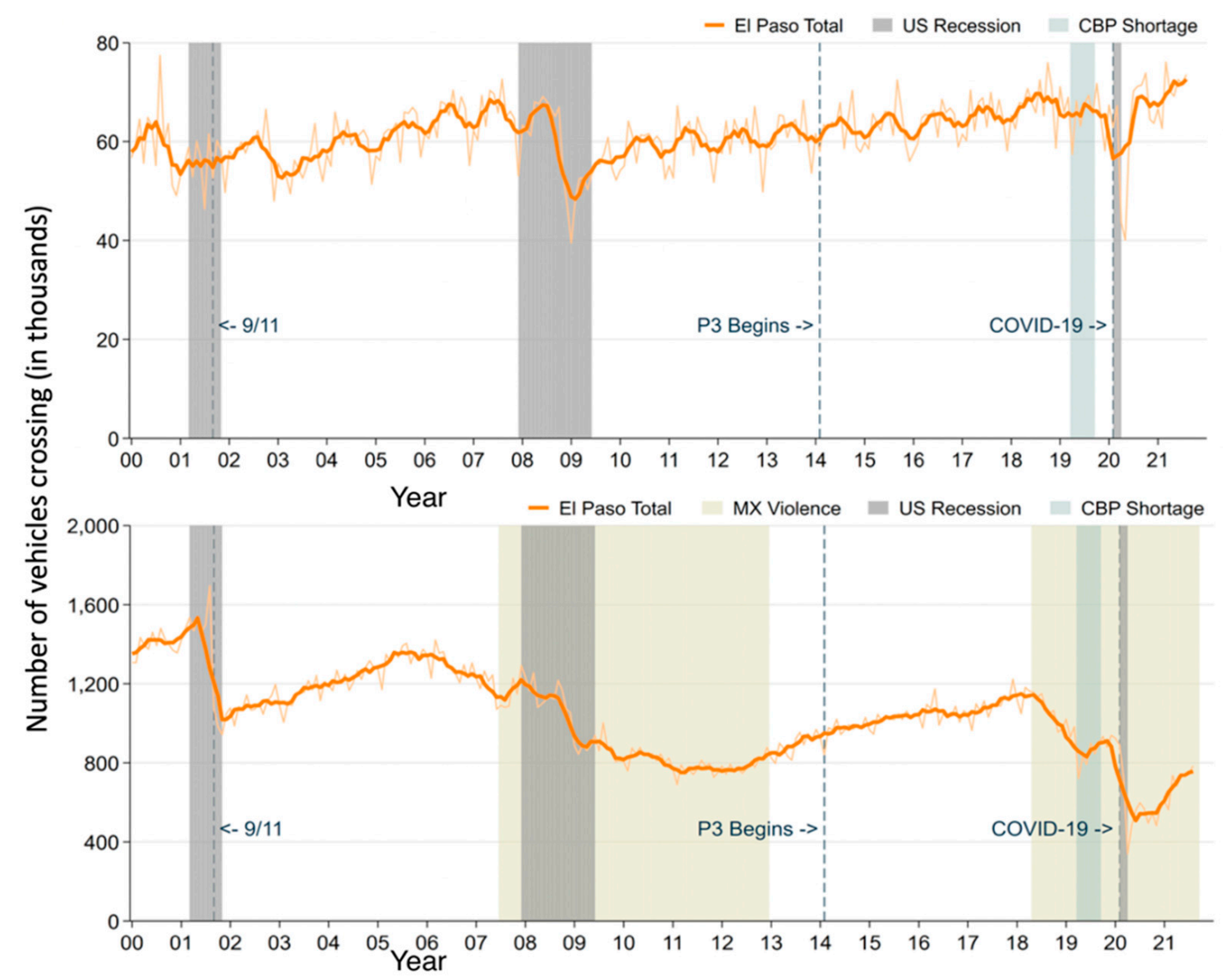

Figure 3. Cargo trucks (top) and personal vehicles (bottom) crossing the EPJ international borders in thousands in last two decades. A significant drop in both the commercial and private vehicles can be seen in 2008-2009 and 2020. Source: pdnuno.com.

\subsection{Impacts of PBL on High Ozone Events}

The PBLH is an important factor in air quality because it is related to the volume in which pollutants are mixed and dispersed [33]. Several studies have shown that during the high ozone events in EPJA, shallow PBLHs were observed [8,9,34]. However, these studies were limited to the specific events, and the region's annual PBL structure for this region was not examined. In this section, we explore the PBLHs during some of the high and low ozone events during the lengthy study period. We also analyze as a representative sample the annual pattern of the PBL, ozone, and some meteorological parameters for the year 2019.

In this study, an event was defined as a low ozone episode when the 8-h average $\mathrm{O}_{3}$ concentration was less than $50 \mathrm{ppbv}$. Based on our previous research, which included a case study of consecutive ozone events in June 2017, we found that a low $\mathrm{O}_{3}$ event occurred in the late summer and early fall season just like high ozone events [9]. The impact of PBL on both the high and low ozone events during the short study period (June 4-7 and June 11-13 respectively) is elaborately analyzed in this work. To investigate the role of PBL during high and low ozone events covering multiple years, we calculated hourly PBLH values from the UTEP ceilometer using the proprietary software boundary layer view (BL-view), and the maximum height during the event was recorded. The EPJA recorded 46 high ozone days between 2015 and 2019, with ceilometer data available for 20 of them. Table 1 shows the high, and low ozone events from 2015 to 2019 and the maximum PBLH calculated. Most high ozone days had shallow PBLH around $2000 \pm 250 \mathrm{~m}$, whereas low ozone days had deep PBLH around $2750 \pm 250 \mathrm{~m}$. The PBLH was higher during a high ozone event on June 6th and 7th, 2017, and 26 July 2019. Similarly, on 14 May 2018, a day 
of low ozone event, PBL was shallower than the rest of the recorded low ozone events. The ceilometer recorded early morning light precipitation on 8 occasions during the 20 high ozone events listed in Table 1. On 6 occasions, the maximum PBLH was observed to be less than $1700 \mathrm{~m}$, indicating that PBL growth was suppressed due to an increase in humidity in the air. On the contrary, most of the low ozone events with deep PBLHs had a high concentration of aerosols in the air, which can be attributed to strong winds coming from the West, Southwest of the EPJA, carrying dust from the Chihuahua desert. In summary, on days with high ozone exceedances, the PBL was shallow compared to low ozone days.

Table 1. High ozone $\left(\mathrm{HO}_{3}\right)$ and low ozone $\left(\mathrm{LO}_{3}\right)$ events from 2015-2019, for which daytime maximum PBLH was calculated.

\begin{tabular}{|c|c|c|c|}
\hline $\begin{array}{l}\text { Day and Year } \\
\qquad\left(\mathrm{HO}_{3}\right)\end{array}$ & $\begin{array}{c}\text { Daytime Max. PBLH } \\
\pm 250 \mathrm{~m}\end{array}$ & $\begin{array}{l}\text { Day and Year } \\
\left(\mathrm{LO}_{3}\right)\end{array}$ & $\begin{array}{c}\text { Daytime Max. PBLH } \\
\pm 250 \mathrm{~m}\end{array}$ \\
\hline 17 June 2015 & 1700 & 15 May 2015 & 3000 \\
\hline 21 June 2015 & 1800 & 18 May 2015 & 2500 \\
\hline 10 August 2015 & 1600 & 5 June 2015 & 2980 \\
\hline 6 June 2016 & 1700 & 1 May 2016 & 2850 \\
\hline 23 June 2016 & 2000 & 16 May 2016 & 3500 \\
\hline 16 July 2016 & 2000 & 13 June 2016 & 3300 \\
\hline 8 August 2016 & 2500 & 29 June 2016 & 3010 \\
\hline 4 June 2017 & 1600 & 25 May 2017 & 3300 \\
\hline 5 June 2017 & 1700 & 11 June 2017 & 2900 \\
\hline 6 June 2017 & 3200 & 12 June 2017 & 2800 \\
\hline 7 June 2017 & 2980 & 13 June 2017 & 3500 \\
\hline 28 July 2017 & 2800 & 11 May 2018 & 2950 \\
\hline 12 September 2017 & 2200 & 12 May 2018 & 2500 \\
\hline 04 June 2018 & 2600 & 13 May 2018 & 2700 \\
\hline 15 July 2019 & 1600 & 14 May 2018 & 2000 \\
\hline 26 July 2019 & 3500 & 7 May 2019 & 3500 \\
\hline 27 July 2019 & 1400 & 8 May 2019 & 3100 \\
\hline 7 August 2019 & 1600 & 10 May 2019 & 2500 \\
\hline 10 August 2019 & 1600 & 11 May 2019 & 2950 \\
\hline 15 August 2019 & 1500 & 17 May 2019 & 3650 \\
\hline
\end{tabular}

Temperature, wind speed, atmospheric pressure, and humidity are all important meteorological variables in the formation, development, and depletion of ozone. Figure 4 shows the annual plots of ozone concentrations (top, 1), followed by solar radiation, clear sky photolysis frequencies of $\mathrm{NO}_{2}$ and $\mathrm{O}_{3}$ (2), daily maximum PBLH (3), and afternoon wind speeds in black and air temperature in red (bottom, 4) from the UTEP/CAMS 12 monitoring site showing their seasonal behavior. In Figure 4 (1), the blue line marks the hourly 71 ppbv of $\mathrm{O}_{3}$ concentrations. The $\mathrm{O}_{3}$ concentrations show gradual growth entering the $\mathrm{O}_{3}$ season from May until September when we notice several data points above the blue line and decreases after that. There were days within the ozone season that also recorded lower levels of ozone. More data points were observed at $0-40 \mathrm{ppbv}$ levels in the fall and winter seasons, indicating lower to moderate regional $\mathrm{O}_{3}$ concentrations, whereas fewer data points were observed at $0-20 \mathrm{ppbv}$ levels in the summer season, indicating that ozone concentrations do not fall below certain levels. Analysis of 1 and 2 showed the dependence of $\mathrm{O}_{3}$ production on solar radiation; however, most of the high $\mathrm{O}_{3}$ events occur in the late half of the maximum annual photolysis frequency curves. The photolysis frequencies 
of ozone, $\mathrm{JO}_{3}$, (the $\mathrm{HO}$ radical source) shows a stronger seasonal dependence than the photolysis frequency of $\mathrm{NO}_{2}, \mathrm{JNO}_{2}$, (the direct $\mathrm{O}_{3}$ source). Much detailed discussions and findings on the dependencies of ozone production on precursors ( $\mathrm{NO}_{\mathrm{x}}$ and VOC) and solar radiation can be found in Stockwell et al. [35]. High ozone levels occur in the second half of the year, most likely due to increased local biogenic and anthropogenic VOC emissions. During the fall and winter seasons, daily maximum ozone values are found to be well below $50 \mathrm{ppbv}$. PBLH grows gradually, and peak heights are recorded in the summer months. In the latter half of the summer, as the percentage relative humidity in the air increases after the American monsoon's arrival, PBLHs tend to be shallower. Additionally, seen in Figure 4, shallower PBLHs correspond to the high $\mathrm{O}_{3}$ days, indicating it is most likely contributed to the high $\mathrm{O}_{3}$ concentrations in the area by restricting dispersion in the vertical direction. On the contrary, the spring season does not have any high $\mathrm{O}_{3}$ episodes due to low biogenic VOC emissions, higher PBLHs, and high ventilation factor, i.e., higher horizontal wind speeds during spring than in the fall season, ultimately affecting the PBLH as well. This conclusion can also be confirmed by the fact that all the data below were obtained from the same monitoring site.

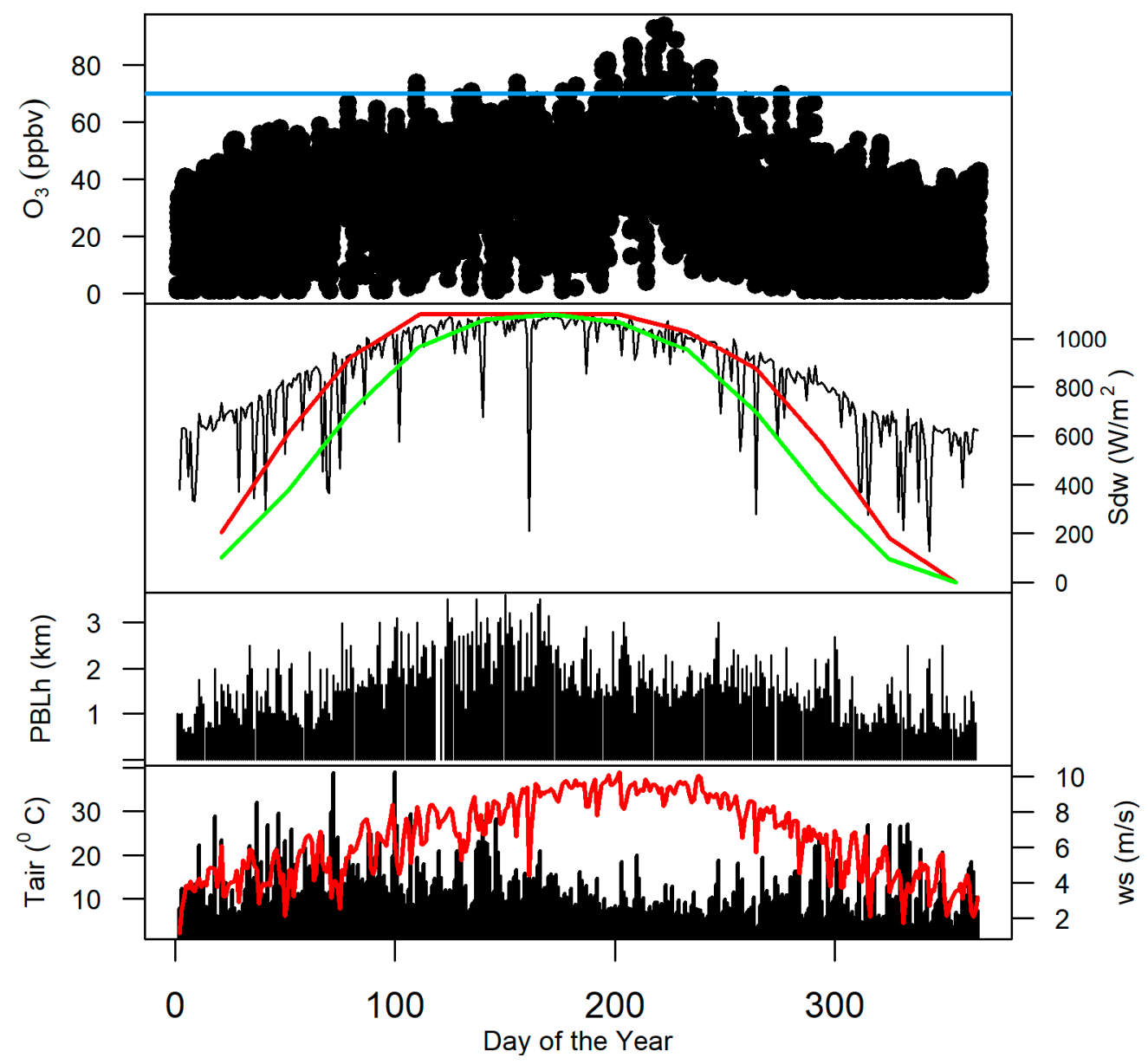

Figure 4. Daily hourly ozone concentration in ppbv (top, 1); downward solar radiation (Sdw), photolysis frequencies of $\mathrm{NO}_{2}$ (red) and $\mathrm{O}_{3}$ (green) (2), maximum daily CBLH in (m) (3), and afternoon average wind speeds in black (between 13-17 p.m.) and daily maximum air temperature in red (bottom, 4) for the year 2019. The blue line at the top marks the $71 \mathrm{ppbv}$ of ozone level.

\subsection{Synoptic Effects on Ozone Concentrations}

Most high $\mathrm{O}_{3}$ days occurred when an anticyclonic circulation aloft linked with a middle and upper tropospheric high-pressure region was centered within $800 \mathrm{~km}$ of the EPJA. The high-pressure center was usually positioned west or north of EPJA, as seen 
below (Figure 5). The presence of a high-pressure ridge implied that large-scale subsidence or sinking motion was common in the area, which leads to stable atmospheric conditions that tend to trap pollutants. The pressure gradient was modest in the lower troposphere, including the surface; thus, winds were typically light at less than $12 \mathrm{~km} / \mathrm{h}$. Temperatures in El Paso were often near or above average and frequently exceeded $32{ }^{\circ} \mathrm{C}$, consistent with most high $\mathrm{O}_{3}$ occurrences during the year's hottest months, June, July, and August. The soundings showed a weakly unstable air mass with a convective accessible potential energy of less than $500 \mathrm{~J} / \mathrm{kg}$. The air mass was generally dry below $700 \mathrm{hPa}$, with the relative humidity from $700 \mathrm{hPa}$ to the surface layer being less than $40 \%$. Rain was observed at El Paso Airport on 11 of the 34 event days, possibly due to the monsoon season. Most of the time, the rainfall was modest, with quantities less than 0.05 inches each day.
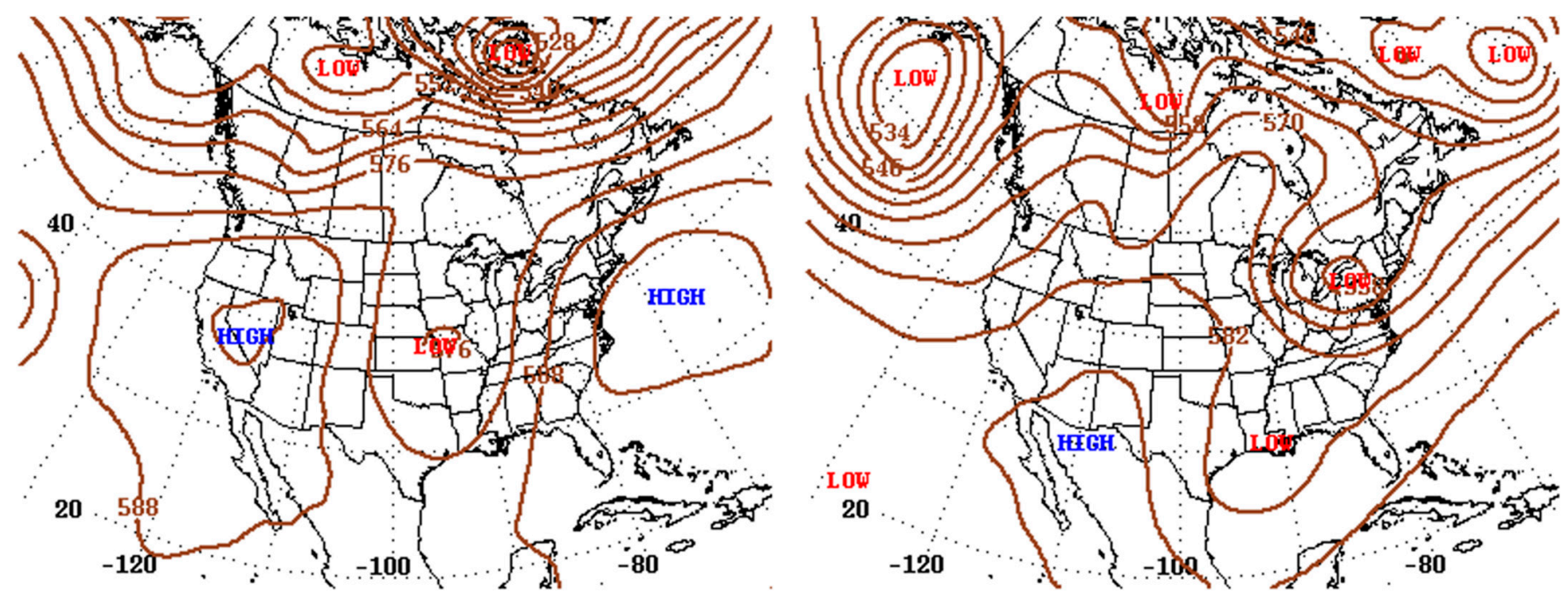

Figure 5. 500 hPa height contour at 5:00 a.m. MST on 03 July 2013 (left) and 06 June 2017 (right), both high ozone episodes. The presence of a high-pressure ridge around and over the EPJA can be seen during the ozone exceedance event.

An air parcel's vertical motion is inversely correlated with atmospheric thermal stability. Convective available potential energy (CAPE) is the amount of energy available to a parcel as it rises freely between the level of free convection (LFC) and the equilibrium level (EL). CAPE is indicative of the development of a convective process. It becomes non-zero only if LFC exists. A CAPE value of $0 \mathrm{~J} / \mathrm{kg}$ indicates a stable environment, a CAPE of less than or equal to $500 \mathrm{~J} / \mathrm{kg}$ indicates mildly unstable conditions, a CAPE of $1000-2500 \mathrm{~J} / \mathrm{kg}$ are unstable while conditions with a CAPE of 2500-3500 J/ kg are precarious. CAPE of more than $3500 \mathrm{~J} / \mathrm{kg}$ indicates that the atmosphere is in a turbulent state. Variations in CAPE values observed during field experiments in midcontinental North America have been attributed primarily to changes in the temperature and humidity in the PBL. CAPE and the PBL are coupled in both convective and non-convective conditions. Coupling under deep convection conditions implies that the intensity of deep convection is constrained [36,37].

Atmospheric vertical profile measurements from the daily radiosonde launch from the nearest NWS site around $20 \mathrm{~km}$ to the west of EPJ were used to analyze regional atmospheric stability. The NWS launches two radiosondes daily at $00 \mathrm{Z}$ and $12 \mathrm{Z}$, respectively. As shown in Figure 6, Low CAPE values reflect air stability for most high $\mathrm{O}_{3}$ occurrences and indicate weak or no convective mixing within the PBL. This finding supports the ground-based wind speed observations finding calm winds and stagnant conditions favorable for increased pollution levels. There were a few occasions when the atmosphere was slightly unstable. The CAPE value was 1093 Joule/kg on 11 July 2013, at 12 Z, suggesting moderately unstable atmospheric conditions. This moderate nonlocal conditional instability ensued when a temperature inversion capped warm, humid atmospheric boundary layer air. 


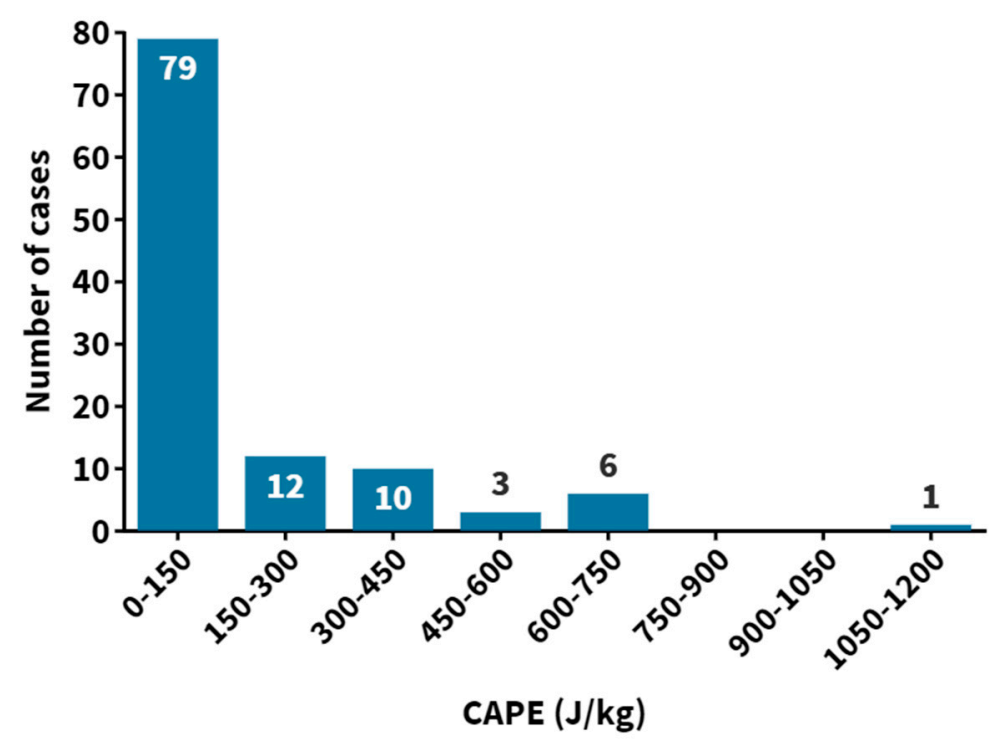

Figure 6. CAPE values for all the 57 high ozone episodes that occurred in 2013-2019. Note, data from the $00 \mathrm{Z}$ and $12 \mathrm{Z}$ radiosondes launched during the high ozone day were obtained. Out of 114 launches, data from 3 launches were not available for analysis.

\subsection{Mesoscale and Local Circulations during the Ozone Events}

In our previous work on the June 2017 ozone events, we analyzed the surface wind directions at CAMS 12 UTEP during both the high and low ozone events. We found that during the high ozone winds were predominantly from the East and Southeast direction and during the low ozone events, strong winds were from the West of EPJA [9]. To better understand the long-term impact of winds on $\mathrm{O}_{3}$ in the region over the span of three years (2016-2018), the region's airflow features, such as slope flows and mountain-valley circulations, were analyzed using wind data from different CAMS in the region. The plots in Figure 7 show the complexity of the wind patterns in the EPJA. UTEP, Socorro and El Paso Lower Valley have two distinct modes, aligning with the Rio Grande rift valley. Ojo De Agua CAMS located on the Eastern foothills of the Franklin Mountain also showed 2 modes, but it was more consistent with the katabatic/anabatic winds pattern, which during the daytime is anabatic/upslope (about $250^{\circ}$ ), and during nighttime is katabatic/downslope (about $80^{\circ}$ ). Skyline Park CAMS located on the Western foothills of the mountain showed the most complex wind patterns with a topographic wind and a peak of the westerly winds. UTEP CAMS high ozone histogram showed that ozone episodes mostly happened when the winds were from the East, with the wind speeds lower than the averaged wind.

The valley where the downtown area of EPJ is located is approximately $100 \mathrm{~m}$ below the surrounding plateau, and the Franklin Mountains are approximately $700 \mathrm{~m}$ above the plateau. Figure 1 depicts the abrupt elevation drops appearing from west to east in the southern Franklins. These complex mountain ridges and valleys trap air masses containing $\mathrm{O}_{3}$ and its precursors and particulate matter (PM), limiting pollutant dispersal and contributing to high $\mathrm{O}_{3}$ and PM episodes $[9,13,18]$. Data from the Radio Wind Profile (RWR) located at CAMS 49 Socorro were used to make histograms to analyze the daytime winds at different height levels for 2017, Figure 8. Wind frequency and direction were measured for three different levels/heights above the ground. At the $2.2 \mathrm{~km}$ height which is well above the Franklins, the histograms show climatological predominant winds, mostly the Westerlies (about $260^{\circ}$ ). Within the valley, there was a second peak at $100^{\circ}$ and at the West sector peek veers towards North $\left(280^{\circ}\right)$ at $0.498 \mathrm{~km}$ and $290^{\circ}$ at $0.146 \mathrm{~km}$. This observation was consistent with the winds at the closest CAMS (Socorro and El Paso Lower Valley) as seen in Figure 7. 


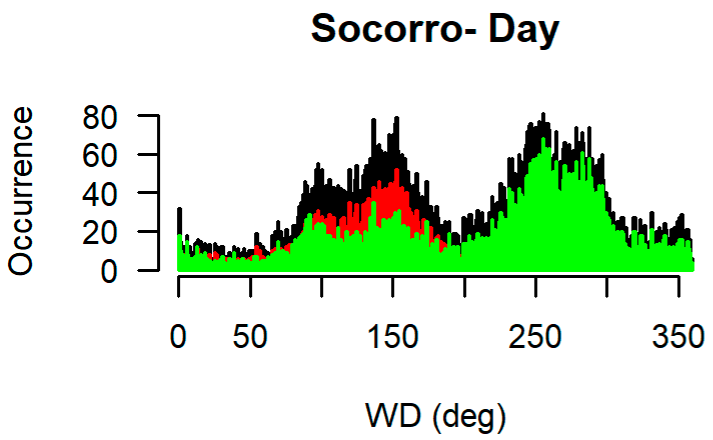

OjoDeAgua

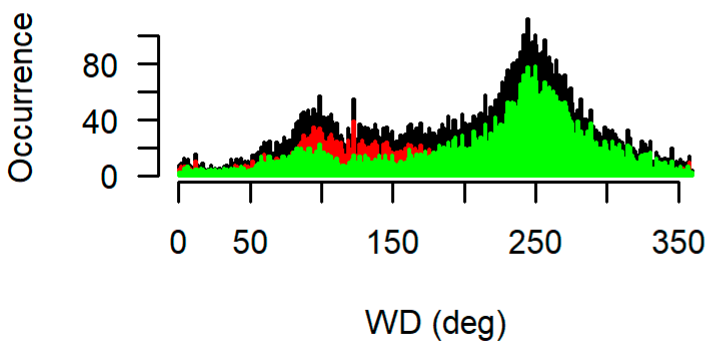

UTEP

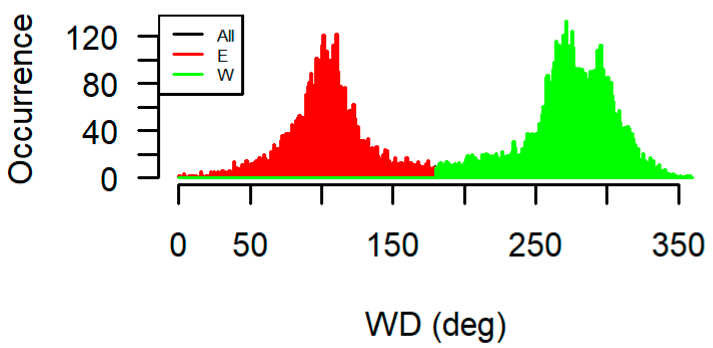

EPLowerValley

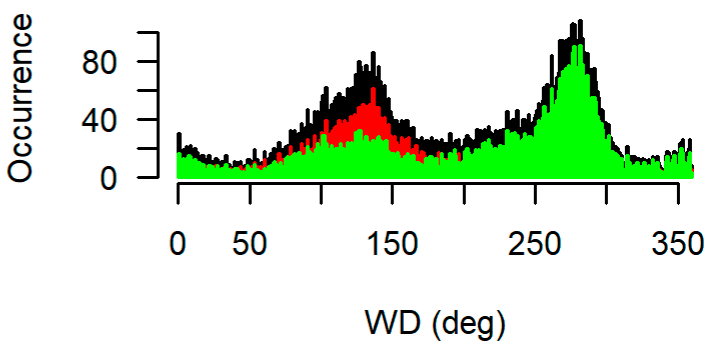

SkylinePark

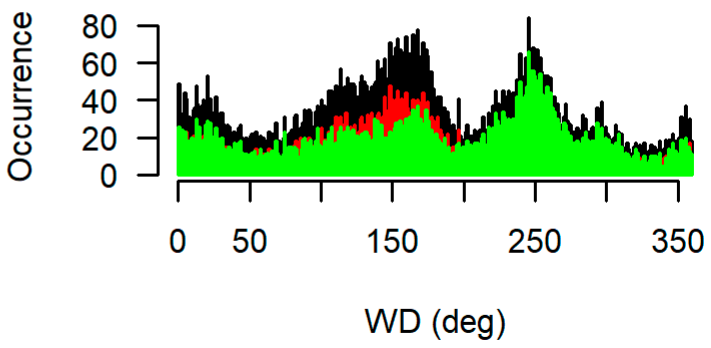

UTEP

Wind Direction at High 03 Days

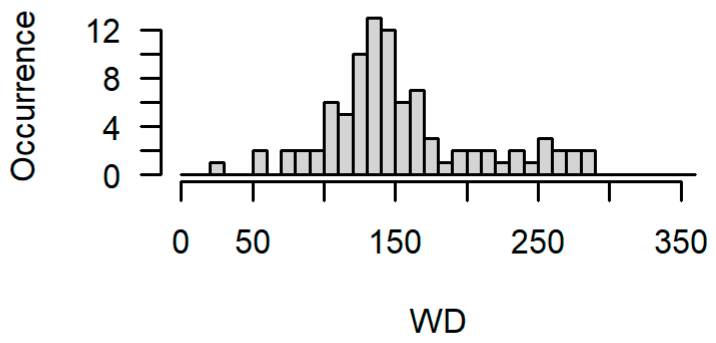

Figure 7. Histograms of the horizontal meteorological wind directions during the 2016-2018 for TCEQ CAMS Socorro, El Paso lower valley, Ojo De Agua, Skyline Park, and UTEP. The red and green correspond to the Easterly and Westerly wind direction at the UTEP CAMS, respectively. The bottom right corner plot shows the wind direction histogram for high ozone days (O3 > $70 \mathrm{ppbv})$ at UTEP CAMS.

Both the synoptic and local winds play a role in enhancing the ozone concentrations in the region. It was observed that most of the high ozone events occurred when the winds were calm and coming from the East, Southeast direction. When the surface wind strengths were moderate to strong, ozone precursor emissions were dispersed [27]. In Figure 9, we observe two wind patterns throughout the year. Westerly winds at the top level $(2.514 \mathrm{~km})$, shown in the yellow box, are the predominant climatological wind direction (Westerly $240^{\circ}-250^{\circ}$ ) which can be attributed to the synoptic conditions prevailing in the West, Northwest of EPJA as seen in Section 3.2, Figure 5. High $\mathrm{O}_{3}$ data (red triangles) in Figure 9 was taken above the threshold value of $70 \mathrm{ppbv}$ in the hourly averaged $\mathrm{O} 3$ mixing ratios (as shown in Figure 4).

On the other hand, Easterly winds at the bottom level, near the ground surface $(0.146 \mathrm{~km})$ shown in the green box, result from the channeling of winds due to the local topography. The direction of the surface winds' flow was frequently observed to be at an angle with respect to the valley's orientation [38]. Most of the high ozone episodes 
happened in the channel wind pattern with no discernible coupling with winds aloft. When the wind aloft was strongly coupled with the wind bellow $(180<\mathrm{WD}(2.541)<270)$ and $(180<\mathrm{WD}(0.146)<360)$, few cases of high ozone have been observed, and none were close to the mode of the value (yellowish density points). D. Whiteman and Doran C. [39], R. Weber and P. Kaufmann [40], and Sakai et al. [41] investigated the relationship between synoptic winds, valley winds, and complex terrain. They attributed such decoupling to thermal forcing, which generates within-valley winds via locally developed along-valley pressure gradients rather than wind directions above the valley. These pressure gradients, common in valley meteorology, are generated hydrostatically from temperature differences that form along the valley axis $[39,40]$.

EP Wind Profiler Daytime: year 2016-2018 - Doy: 1-366 Level: $0.146 \mathrm{~km}$

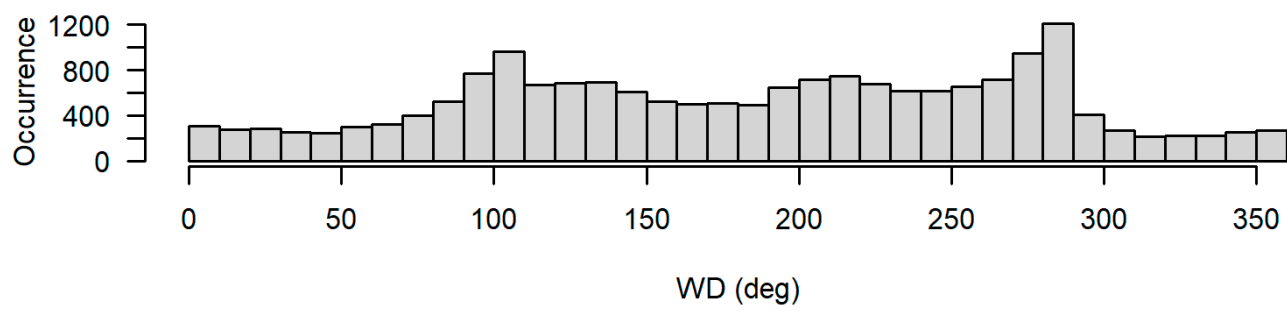

Level: $0.498 \mathrm{~km}$

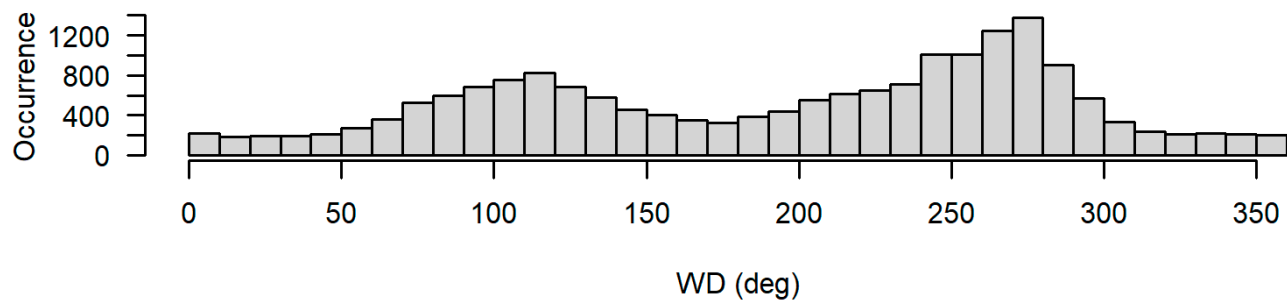

Level: $2.541 \mathrm{~km}$

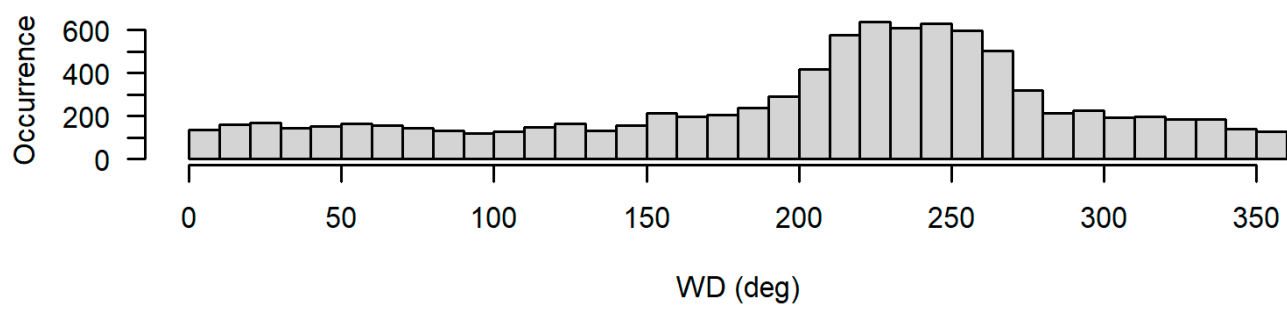

Figure 8. Histogram of wind direction at several levels (top) at $0.146 \mathrm{~km}$ (middle) at $0.498 \mathrm{~km}$, and (bottom) at $2.251 \mathrm{~km}$. 


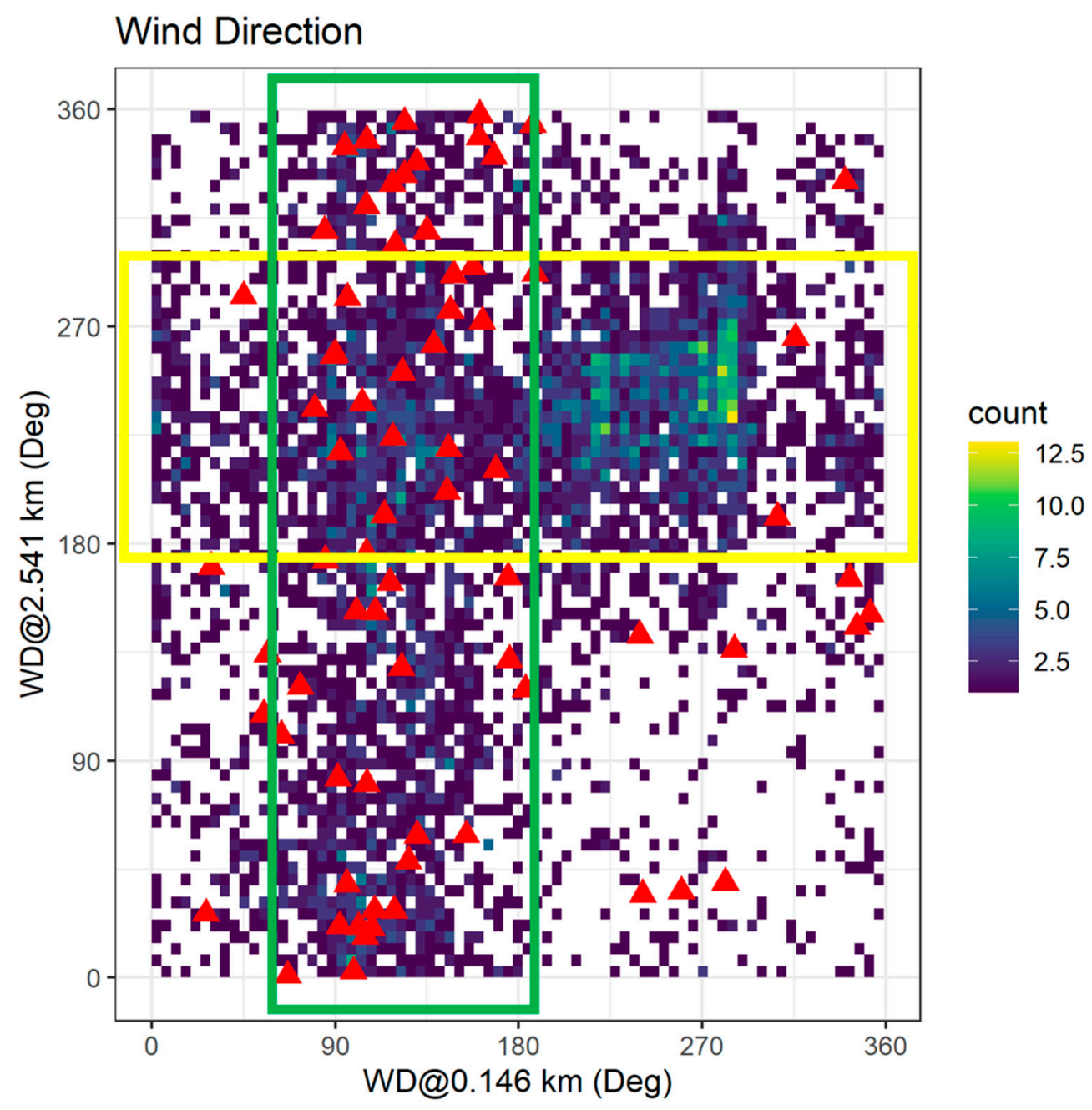

Figure 9. Density plot of the wind directions from two levels (x: $0.146 \mathrm{~km}, \mathrm{y}: 2.541 \mathrm{~km})$ using the Socorro Radio Wind Profiler data. Red triangles are related to days with high ozone mixing ratios.

Figure 10 shows the trajectory endpoints contoured to reflect the density of points between 50 and 200 miles from the center of the EPJA on high ozone days, with the highest concentration of endpoints to the Southeast and East. Additional steps were taken to perform PSCF to estimate possible upwind source areas from back-trajectory calculations. In this application, rather than using the 57 MDA8 exceedance days, the threshold for "high $\mathrm{O}_{3}$ " was lowered to $65 \mathrm{ppbv}$, for which 177 days were available. Additionally, in this application, all trajectories were run at a larger scale, running $120 \mathrm{~h}$ (5 days), using May through September 2013-2019, starting every day at noon MST (19 UTC) from three altitudes-100 m, 500 m, and 1000 m AGL (Figure 11). Trajectory endpoints were filled in by linearly interpolating in between the one-hour time-step trajectory endpoints, increasing the number of points. In several applications of PSCF resolutions of $1 \mathrm{deg}$. Latitude by $1 \mathrm{deg}$. Longitude gridding is used. A shortcoming of this is that at $30 \mathrm{deg}$. Latitude, a degree of Longitude, is 60 miles wide, and a degree of latitude is 69 miles wide. Several approaches at different scales were applied to use smaller square grids, but the simple $1 \mathrm{deg}$. Longitude $\times 1 \mathrm{deg}$. Latitude was found to be satisfactory. PSCF analysis shows that more than 40 percent of the time that an air parcel passes through a red-colored region there is elevated $\mathrm{O}_{3}$ in EPJA. This suggests that air parcels from oil and gas regions in West Texas may contribute to ozone concentrations in EPJA. 


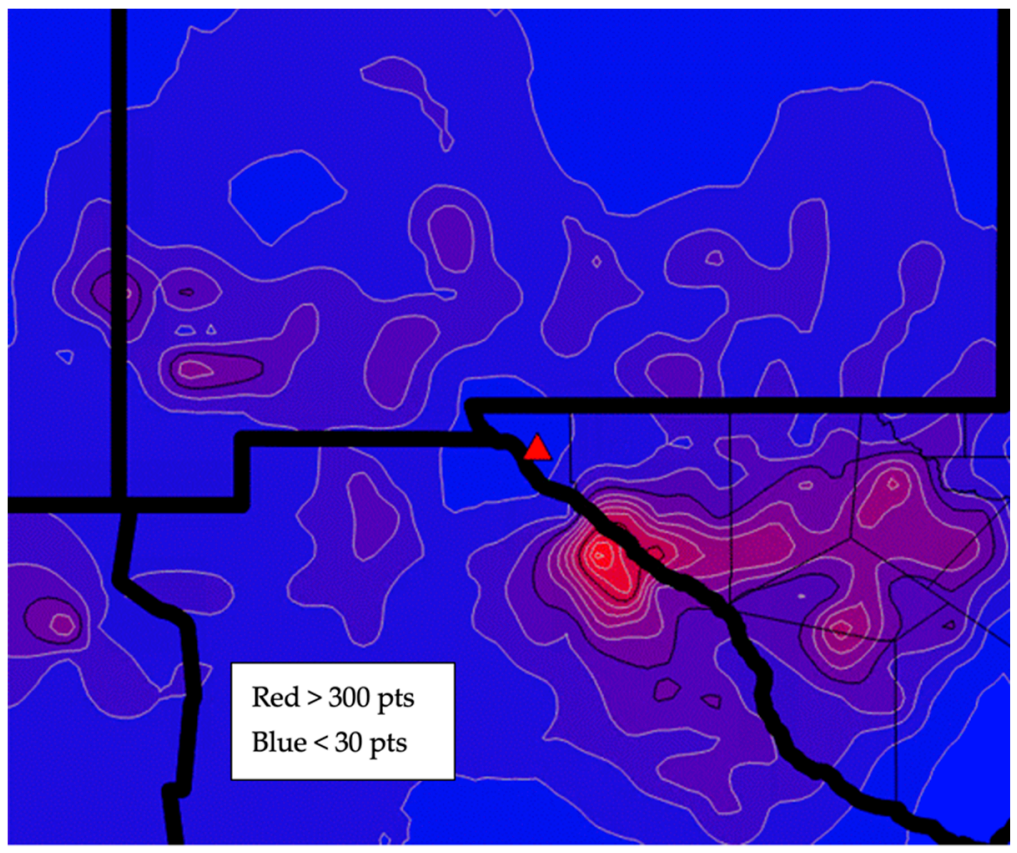

Figure 10. High ozone day back trajectory contouring points $>50$ and $<200$ miles from EPJA.

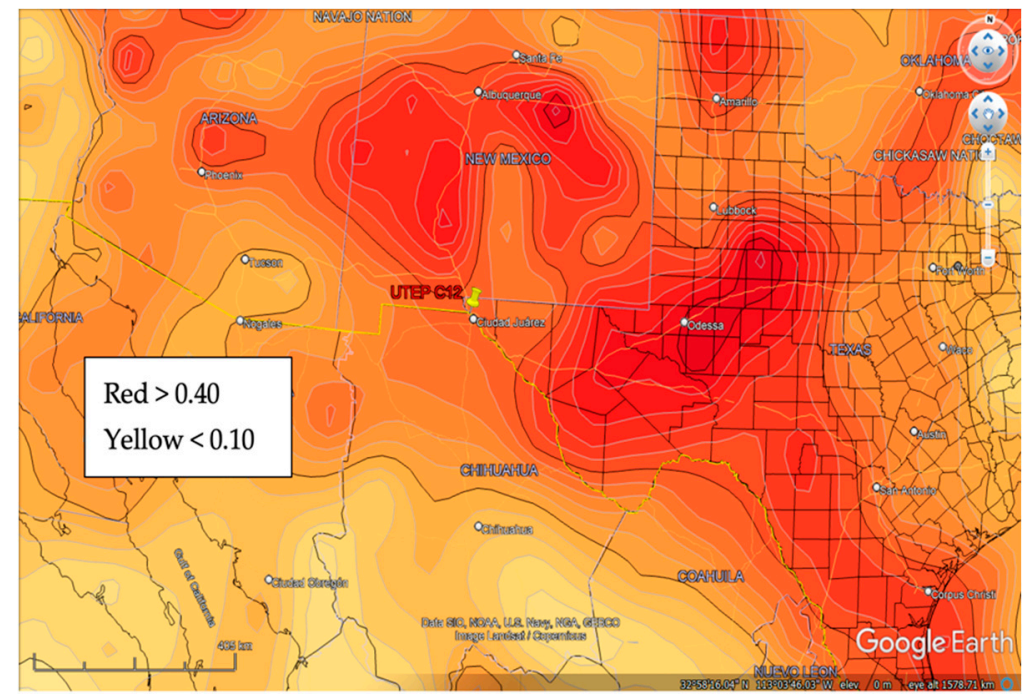

Figure 11. Potential source contribution function for ozone in El Paso, May-September 2013-2019, trajectories run from noon MST (19 UTC) 100 m, 500 m, 1000 m AGL, 1 deg. Long. × 1 deg. Lat., 80 miles to 800 miles from El Paso.

\section{Discussion}

Based on the studies and data reported in this research, an innovative evaluation of the meteorological drivers and air quality features is presented to explain the EPJA's $\mathrm{O}_{3}$ exceedance events. This study was the first systematic, and rigorous long-term spatial and temporal ozone dynamics investigation for the EPJA. Analysis of the two-decade regional high ozone chart, Figure 2, indicated a peculiar fall and rise in high $\mathrm{O}_{3}$ events. The number of yearly high ozone incidents decreased due to a significant fall in private and commercial vehicle crossings and reduced congestions along the US-Mexico international border and the shutdown of industrial units during the 2008 economic recession. This observation agrees with the regional traffic operation and vehicle emission impact assessment reported by Sharifi et al. [31]. The high $\mathrm{O}_{3}$ episodes stayed low for 8 years from 2009-2016 and started rising again from 2017 due to considerably large emissions from the regional 
industrial sources. However, during the pandemic period, when the border crossings were hampered due to severe restrictions, with the exception of commercial trucks, many high ozone events were still observed, indicating that a combination of local anthropogenic and biogenic emissions influence ozone exceedance events in the region. This result was very similar to Lu et al. findings regarding the contribution of local anthropogenic and biogenic VOCs to regional ozone events [12].

Maximum surface temperatures with diurnal variations throughout the $\mathrm{O}_{3}$ season, along with high precursor emissions, created optimal circumstances for photochemistry, culminating in $\mathrm{O}_{3}$ production. In addition to these fundamental circumstances, shallow PBLH and calm surface winds allowed ozone precursors and $\mathrm{O}_{3}$ to accumulate in the region, contributing to increased ozone concentrations. This long-term observation was consistent with the previous study by Karle et al., which discovered similar results for only the selected high ozone events in June 2017 [9].

Examination of the $500 \mathrm{hPa}$ composites revealed a prominent high-pressure ridge over the west or northwest of the study region. This was a typical synoptic meteorological occurrence during the high ozone days. The EPJA saw enhanced atmospheric stability because of this feature [24]. Except for one day, analysis of the CAPE values for all the high ozone days under investigation revealed this atmospheric stability. Vertical mixing of aerosols was restricted in such a steady environment, resulting in the buildup of contaminants. Weak winds flowing within the boundary layer caused poor ventilation conditions, allowing precursor buildup in the region, and resulting in high $\mathrm{O}_{3}$ occurrences. Many high $\mathrm{O}_{3}$ days occurred while El Paso was positioned in an anticyclonic circulation aloft linked with a middle and upper tropospheric high-pressure region centered within 500 miles of the city. This large-scale forcing impacted the evolution and daily maximum PBLH, which is critical for pollutant generation, deposition, mixing, and dispersion. In addition, high temperatures and strong solar radiation were confirmed to be favorable for regional $\mathrm{O}_{3}$ production. High $\mathrm{O}_{3}$ occurrences usually occurred in the latter half of the year when the solar radiation is still at its peak, winds were calm and high humidity in the air due to the arrival of the American monsoon.

The wind patterns around downtown El Paso are distinctively bi-modal, exhibiting Westerly winds at the top level $(2.514 \mathrm{~km})$ of synoptic nature and Easterly winds at the bottom level $(0.146 \mathrm{~km})$, identified as the "channel" pattern. Most of the high ozone episodes happen in the channel pattern with no discernible coupling with the synoptic winds aloft. Furthermore, Easterly surface winds were dominant during most of the high ozone episodes which display a long term agreement with the findings from the case study of 2017 [9]. The air parcel associated with high $\mathrm{O}_{3}$ days showed a preponderance of upwind trajectories to the southeast into northern Mexico and into West Texas, while the random fetches were more broadly distributed to the northwest and southeast. We also noted that during the high ozone events, southeasterly and easterly surface flow patterns were exhibited. According to the contour plots of back trajectories, air parcels from West Texas' oil and gas regions may contribute to ozone concentrations in EPJA. While it was not the intent of our investigation to specifically explore the influence of complex topography on regional circulation patterns, the fact that the CAMS located along the Rio Grande valley exhibit channel flow at the surface certainly suggests the complex role of regional orography. A thorough future research study can be conducted to explore this further.

This research will aid in the development and validation of more accurate meteorological and photochemical models for complex terrain regions by providing a better knowledge of regional meteorological causes and circulation patterns impacting $\mathrm{O}_{3}$ events.

Author Contributions: Conceptualization: N.N.K. and R.M.F.; methodology: N.N.K., R.K.S., R.M.F. and W.R.S.; software: D.W.S., R.K.S., R.M.F. and W.R.S.; validation: R.K.S., R.M.F., D.W.S. and W.R.S.; formal analysis: R.K.S., R.M.F. and W.R.S.; investigation: N.N.K.; resources: N.N.K., R.K.S., R.M.F., W.R.S. and D.W.S.; data curation: R.K.S. and D.W.S.; writing-original draft preparation: N.N.K.; writing-review and editing: R.K.S., R.M.F. and W.R.S.; visualization: R.K.S., N.N.K. and 
D.W.S.; supervision: R.K.S., R.M.F. and W.R.S.; project administration: R.M.F. and N.N.K.; funding acquisition: R.M.F.All authors have read and agreed to the published version of the manuscript.

Funding: This research was supported by the NOAA/Educational Partnership Program under Cooperative Agreement \#NA16SEC4810006 and the NOAA Cooperative Science Center in Atmospheric Sciences and Meteorology (NCAS-M).

Institutional Review Board Statement: Not applicable.

Informed Consent Statement: Not applicable.

Data Availability Statement: Not applicable.

Acknowledgments: To the NOAA Center for Atmospheric Science-Meteorology (NCAS-M), which is funded by the National Atmospheric Administration/Educational Partnership Program under Cooperative Agreement \#NA16SEC4810006. The authors also wish to thank Eddie Moderow, Fernando Mercado, Erick Gribbin, Sergio Vasquez, Eugenia Posada, Patty de la Cruz and Jose Palacios from the Texas Commission on Environmental Quality (TCEQ) for their intellectual and financial grant support and Joseph Rogash from NOAA's National Weather Service for his valuable input.

Conflicts of Interest: The authors declare no conflict of interest. The funders had no role in the design of the study; in the collection, analyses, or interpretation of data; in the writing of the manuscript, or in the decision to publish the results.

\section{Abbreviations}

$\begin{array}{ll}\text { AGL } & \text { above ground level } \\ \text { ARL } & \text { Air Research Laboratory } \\ \text { ASL } & \text { above sea level } \\ \text { CAMS } & \text { continuous ambient air monitoring station } \\ \text { CBLH } & \text { convective boundary layer height } \\ \text { EPJ } & \text { El Paso-Juarez } \\ \text { EPJA } & \text { El Paso-Juarez Airshed } \\ \text { HYSPLIT } & \text { Hybrid Single-Particle Lagrangian Integrated Trajectory } \\ \text { NOAA } & \text { National Oceanic and Atmospheric Administration } \\ \text { NWS } & \text { National Weather Service } \\ \text { PBL } & \text { Planetary Boundary Layer } \\ \text { PBLH } & \text { planetary boundary layer height } \\ \text { POE } & \text { Ports of Entry } \\ \text { ppbv } & \text { parts per billion per volume } \\ \text { RWP } & \text { Radio Wind Profiler } \\ \text { TCEQ } & \text { Texas Commission on Environmental Quality } \\ \text { UTEP } & \text { University of Texas at El Paso }\end{array}$

\section{References}

1. Seinfeld, J.; Pandis, S. Atmospheric Chemistry and Physics, 2006; John Wiley \& Sons: New Jersey, NJ, USA, 2006.

2. Kaser, L.; Peron, A.; Graus, M.; Striednig, M.; Wohlfahrt, G.; Juráň, S.; Karl, T. Interannual Variability of BVOC Emissions in an Alpine City. Atmos. Chem. Phys. Discuss. 2021, 1-26. [CrossRef]

3. Dominici, F.; Peng, R.D.; Bell, M.L.; Pham, L.; McDermott, A.; Zeger, S.L.; Samet, J.M. Fine Particulate Air Pollution and Hospital Admission for Cardiovascular and Respiratory Diseases. JAMA 2006, 295, 1127-1134. [CrossRef]

4. Zanobetti, A.; Schwartz, J. The Effect of Particulate Air Pollution on Emergency Admissions for Myocardial Infarction: A Multicity Case-Crossover Analysis. Environ. Health Perspect. 2005, 113, 978-982. [CrossRef]

5. Juráň, S.; Grace, J.; Urban, O. Temporal Changes in Ozone Concentrations and Their Impact on Vegetation. Atmosphere 2021, 12, 82. [CrossRef]

6. Zora, J.E.; Sarnat, S.E.; Raysoni, A.U.; Johnson, B.A.; Li, W.-W.; Greenwald, R.; Holguin, F.; Stock, T.H.; Sarnat, J.A. Associations between Urban Air Pollution and Pediatric Asthma Control in El Paso, Texas. Sci. Total Environ. 2013, 448, 56-65. [CrossRef] [PubMed]

7. Delfino, R.J.; Staimer, N.; Gillen, D.; Tjoa, T.; Sioutas, C.; Fung, K.; George, S.C.; Kleinman, M.T. Personal and Ambient Air Pollution Is Associated with Increased Exhaled Nitric Oxide in Children with Asthma. Environ. Health Perspect. 2006, 114, 1736-1743. [CrossRef] [PubMed] 
8. Karle, N.; Mahmud, S.; Fitzgerald, R.M.; Sakai, R.K.; Stockwell, W.R.; Demoz, B.B.; Morris, V.R. Analysis of Regional Meteorology during the Ozone Episodes in the El Paso-Juarez Airshed in the Summer of 2017. In Proceedings of the 99th American Meteorological Society Annual Meeting-AMS, Phoenix, AZ, USA, 6-10 January 2019.

9. Karle, N.N.; Mahmud, S.; Sakai, R.K.; Fitzgerald, R.M.; Morris, V.R.; Stockwell, W.R. Investigation of the Successive Ozone Episodes in the El Paso-Juarez Region in the Summer of 2017. Atmosphere 2020, 11, 532. [CrossRef]

10. MacDonald, C.P.; Roberts, P.T.; Main, H.H.; Dye, T.S.; Coe, D.L.; Yarbrough, J. The 1996 Paso Del Norte Ozone Study: Analysis of Meteorological and Air Quality Data That Influence Local Ozone Concentrations. Sci. Total Environ. 2001, 276, 93-109. [CrossRef]

11. Brown, M.J.; Muller, C.; Wang, G.; Costigan, K. Meteorological Simulations of Boundary-Layer Structure during the 1996 Paso Del Norte Ozone Study. Sci. Total Environ. 2001, 276, 111-133. [CrossRef]

12. Lu, D.; Reddy, R.S.; Fitzgerald, R.; Stockwell, W.R.; Williams, Q.L.; Tchounwou, P.B. Sensitivity Modeling Study for an Ozone Occurrence during the 1996 Paso Del Norte Ozone Campaign. Int. J. Environ. Res. Public. Health 2008, 5, 181-203. [CrossRef] [PubMed]

13. Einfeld, W.; Church, H.W.; Yarbrough, J.W. Winter Season Air Pollution in El Paso-Ciudad Juarez; US Environmental Protection Agency, Region VI, Air, Pesticides \& Toxics Division: Atlanta, GA, USA, 1995.

14. Stockwell, W.R.; Fitzgerald, R.M.; Lu, D.; Perea, R. Differences in the Variability of Measured and Simulated Tropospheric Ozone Mixing Ratios over the Paso Del Norte Region. J. Atmos. Chem. 2013, 70, 91-104. [CrossRef]

15. Walter, P.J.; Morris, G.A.; Flynn, J.; Kotsakis, A.; Spychala, M.D.; DuBois, D.W.; Wooten, M.; Trevino, K.; Fitzgerald, R.M. Analysis of Ozonesonde and Surface Measurements in San Antonio and El Paso during 2017 and 2019. In Proceedings of the American Geophysical Union, Fall Meeting 2019, San Francisco, CA, USA, 9-13 December 2019.

16. Fujita, E.M. Hydrocarbon Source Apportionment for the 1996 Paso Del Norte Ozone Study. Sci. Total Environ. 2001, 276, 171-184. [CrossRef]

17. Mahmud, S.; Karle, N.N.; Fitzgerald, R.M.; Lu, D.; Nalli, N.R.; Stockwell, W.R. Intercomparison of Sonde, WRF/CAMx and Satellite Sounder Profile Data for the Paso Del Norte Region. Aerosol Sci. Eng. 2020, 4, 277-292. [CrossRef]

18. Karle, N.N. Studies of the Planetary Boundary Layer and Their Impact on Air Pollution in a Semi-Arid Region with Complex Terrain. Ph.D. Thesis, The University of Texas at El Paso, El Paso, TX, USA, 2021.

19. Karle, N.N. Study of the Urban Heat Island and Its Effect on the Planetary Boundary Layer for the El Paso-Juarez Airshed. In Proceedings of the Americal Geophysical Union, New Orleans, LA, USA, 11-15 December 2017; p. A51A-2032. [CrossRef]

20. Münkel, C. Mixing Height Determination with Lidar Ceilometers-Results from Helsinki Testbed. Meteorol. Z. 2007, 16, 451-459. [CrossRef]

21. Schafer, K.; Emeis, S.M.; Rauch, A.; Munkel, C.; Vogt, S. Determination of Mixing Layer Heights from Ceilometer Data. In Proceedings of the Remote Sensing of Clouds and the Atmosphere IX—SPIE, Gran Canaria, Spain, 30 November 2004; Volume 5571, pp. 248-259.

22. Ecklund, W.L.; Carter, D.A.; Balsley, B.B.; Currier, P.E.; Green, J.L.; Weber, B.L.; Gage, K.S. Field Tests of a Lower Tropospheric Wind Profiler. Radio Sci. 1990, 25, 899-906. [CrossRef]

23. Stein, A.F.; Draxler, R.R.; Rolph, G.D.; Stunder, B.J.B.; Cohen, M.D.; Ngan, F. NOAA's HYSPLIT Atmospheric Transport and Dispersion Modeling System. Bull. Am. Meteorol. Soc. 2015, 96, 2059-2077. [CrossRef]

24. Fitzgerald, R.M.; Mahmud, S.; Karle, N.; Stockwell, W.R.; Sullivan, D.; Rogash, J. Analysis of Mesoscale and Synoptic Scale Meteorological Influences on Ozone; Project Report; Texas Commission on Environmental Quality: Austin, TX, USA, 2020.

25. Comrie, A.C.; Yarnal, B. Relationships between Synoptic-Scale Atmospheric Circulation and Ozone Concentrations in Metropolitan Pittsburgh, Pennsylvania. Atmos. Environ. Part B Urban Atmos. 1992, 26, 301-312. [CrossRef]

26. Trends in Fuel Production in the Permian Basin, 2011-2021. Available online: https://www.eia.gov/petroleum/drilling/pdf/ permian.pdf (accessed on 1 November 2021).

27. Pearson, R.; Fitzgerald, R. Application of a Wind Model for the El Paso-Juarez Airshed. J. Air Waste Manag. Assoc. 2001, 51, 669-680. [CrossRef]

28. Solomon, P.; Cowling, E.; Hidy, G.; Furiness, C. Comparison of scientific findings from major ozone field studies in North America and Europe. Atmos. Environ. 2000, 34, 1885-1920. [CrossRef]

29. Grineski, S.E.; Collins, T.W.; Chakraborty, J.; McDonald, Y.J. Environmental Health Injustice: Exposure to Air Toxics and Children's Respiratory Hospital Admissions in El Paso, Texas. Prof. Geogr. 2013, 65, 31-46. [CrossRef]

30. Fitzgerald, R.M.; Karle, N.N.; Lara, P.; Polanco, J.; Stockwell, W.R. Optical Measurements of Particulate Matter in the El PasoJuárez Region: Natural Mineral Dust and Soot. In EM Magazine; Air \& Waste Management Association: Pittsburgh, PA, USA, 2021.

31. Sharifi, F.; Meitiv, A.; Shelton, J.; Xu, X.; Burris, M.; Vallamsundar, S.; Xu, Y.A. Regional Traffic Operation and Vehicle Emission Impact Assessment of Lane Management Policies. Res. Transp. Econ. 2021, 87, 101067. [CrossRef]

32. Cambridge Systematics, Inc. "Economic Role of the El Paso Border Crossings, Technical Memorandum" for Texas Department of Transportation, February 2011. Available online: http://www.remi.com/wp-content/uploads/2017/12/105-CambridgeSystematics-Economic-Role-of-the-El-Paso-Border-Crossings.pdf (accessed on 10 October 2021).

33. Hallar, A.G.; Brown, S.S.; Crosman, E.; Barsanti, K.C.; Cappa, C.D.; Faloona, I.; Fast, J.; Holmes, H.A.; Horel, J.; Lin, J.; et al. Coupled Air Quality and Boundary-Layer Meteorology in Western U.S. Basins during Winter: Design and Rationale for a Comprehensive Study. Bull. Am. Meteorol. Soc. 2021, 102, E2012-E2033. [CrossRef] 
34. Karle, N.; Mahmud, S.; Fitzgerald, R.; Estes, M.; Walter, P.; Morris, G. Analysis of Boundary Layer Heights Using Ceilometer and Models in the El Paso-Juarez Airshed. In Proceedings of the 101st American Meteorological Society Annual Meeting, Online, 10-15 January 2021.

35. Stockwell, W.R.; Lawson, C.V.; Saunders, E.; Goliff, W.S. A Review of Tropospheric Atmospheric Chemistry and Gas-Phase Chemical Mechanisms for Air Quality Modeling. Atmosphere 2012, 3, 1-32. [CrossRef]

36. Donner, L.J.; Phillips, V.T. Boundary Layer Control on Convective Available Potential Energy: Implications for Cumulus Parameterization. J. Geophys. Res. Atmos. 2003, 108, 4701. [CrossRef]

37. Athanassiadis, G.A.; Rao, S.T.; Ku, J.-Y.; Clark, R.D. Boundary Layer Evolution and Its Influence on Ground-Level Ozone Concentrations. Environ. Fluid Mech. 2002, 2, 339-357. [CrossRef]

38. Gross, G.; Wippermann, F. Channeling and countercurrent in the upper Rhine valley: Numeric simulations. J. Clim. Appl. Meteol. 1987, 26, 1239-1304. [CrossRef]

39. Whiteman, C.D.; Doran, J.C. The relationship between overlying synoptic-scale flows and winds within a Valley. J. Appl. Meteol. 1993, 32, 1669-1682. [CrossRef]

40. Webber, R.O.; Kaufmann, P. Relationship of synoptic winds and complex terrain flows during MISTRAL field experiments. J. Appl. Meteol. 1998, 37, 37-1468. [CrossRef]

41. Sakai, R.K.; Fitzjarrald, D.R.; Walcek, C.; Czikowsky, M.J.; Freedman, J.M. Wind Channeling in the Hudson Valley, NY. In Proceedings of the American Meteorological Society Annual Meeting 2006, San Diego, CA, USA, 21-25 May 2006. 